\title{
Notes about the modalities of social
}

intervention facing lesions and deaths caused by traffic accidents related to the consumption of alcoholic beverages'

\section{Apontamentos sobre as modalidades de intervenção social no enfrentamento das lesões e mortes causadas por acidentes de trânsito relacionados ao consumo de bebida alcoólica}

\section{Marcilio Sandro de Medeiros}

Fundação Oswaldo Cruz. Instituto Leônidas e Maria Deane. Manaus, AM, Brazil.

E-mail: muribekaœhotmail.com

\section{Correspondence}

Rua Teresina, 476, Adrianópolis.

Manaus, AM, Brazil. CEP 69057-070.
Abstract

This essay aims to reflect, in the light of the concepts of biopower and symbolic market, on the modalities of social intervention in facing of lesions and deaths caused by traffic accidents related to the consumption of alcoholic beverages. The study identified that the two State initiatives in reducing lesions and deaths from traffic accidents involving drunk driving act on risk management, which is a new perspective at the regulatory framework that defines the contemporary citizen (homo medicus). Thus, the responsibility to eradicate risk behavior is transferred to individuals, encouraging them to increasingly behave like entrepreneurs of themselves and their health, life, and environment, which constitutes biossociability determined by the Structure of Biopower, as announced by Michel Foucault. Driving a vehicle under the influence of alcoholic beverages is determined by a logic of production and consumption organized by the logic of economic agents that have on media communication their main dissemination vector. The subjectivity of the symbolic market designed by this logic is protected through legal and financial apparatus of the State, whose content focuses on capitalist accumulation, at the expense of health. It also extols the figure of the consumercitizen within the regulatory and neoliberal rationality that overvalues the individuality in the private sphere and does not promote the engagement with

1 Research conducted with the support from the Research Support Foundation of the State of Amazonas - Fapeam. 
civic potential of consumption or the approximation of individuals with collective problems.

Keywords: Traffic Accidents; Health Programs; Propaganda; Control of the Publicity of Products; Consumption of Alcoholic Beverages; Biopower.

\section{Resumo}

Este ensaio objetiva refletir, à luz dos conceitos de biopoder e de mercado simbólico, sobre as modalidades de intervenção social no enfrentamento às lesões e mortes causadas por acidentes de trânsito relacionados ao consumo de bebida alcoólica. A reflexão identificou que as duas iniciativas do Estado na redução das lesões e mortes por acidentes de trânsito envolvendo embriaguez ao volante agem no gerenciamento do risco, o que constitui um novo olhar sobre o quadro normativo que define o cidadão contemporâneo (homo medicus). Dessa forma, transfere-se aos sujeitos a responsabilidade de erradicar comportamentos de risco, estimulando-os a comportarem-se cada vez mais como empreendedores de si mesmos e de sua saúde, de sua vida e de seu ambiente, o que constitui biossociabilidade determinada pela Estrutura do Biopoder, conforme anunciou Michel Foucault. A condução de veículo sob efeito de bebida alcoólica é determinada por uma lógica de produção e consumo organizada pela lógica dos agentes econômicos que têm na comunicação midiática seu principal vetor de difusão. A subjetividade do mercado simbólico concebida nessa lógica é protegida por meio de anteparos jurídicos e financeiros do Estado, cujo conteúdo privilegia a acumulação capitalista, em detrimento da saúde. Ela ainda enaltece a figura do cidadão-consumidor na racionalidade reguladora neoliberal que hipervaloriza a individualidade na esfera privada e não promove o engajamento com potencial cívico de consumo e nem aproximação dos indivíduos com problemas coletivos.

Palavras-chave: Acidentes de Trânsito; Programas de Saúde; Propaganda; Controle da Publicidade de Produtos; Consumo de Bebidas Alcoólicas; Biopoder.

\section{The problem}

It is estimated that, every year, over 1 million people become victims in traffic accidents worldwide, which represents $12 \%$ of the total deaths in the world's population (Malta et al., 2011).

In Brazil, in 2008, for example, the number and coefficient of deaths caused by traffic accidents was, respectively, 57,116 and 30.1 per 100 thousand inhabitants. Those numbers were higher than those recorded in the United States $(37,261$ deaths and coefficient of 12.5 per 100 thousand inhabitants) and in the European Union (38,876 deaths and coefficient of 7.8 per 100 thousand inhabitants) (CNM, 2010).

Besides the loss of human life, injuries caused by traffic accidents have been increasingly generating social costs. The number of people with permanent disability jumped from 33 thousand, in 2002, to 352 thousand in 2012 (positive variation of 1,066\% in 10 years). Thus, the Brazilian National Social Security Institute (INSS) pays to the victims one million benefits at a cost of 12 billion reais, numbers that tend to grow even more (Brasil, 2013).

The specialized literature in the field of public health has highlighted three main conditions related to structural problems that would explain the traffic violence in the country: (i) infrastructure of cities, in particular that linked to the construction, maintenance, and signalization of roads; (ii) economic dynamism, which provided the increased purchasing power of the population, long-term credit lines for access to motor vehicles, including the introduction of the motorcycle as a means of transport of passengers and as an instrument of work, all contributing to the increase of the fleet; and (iii) attitudes linked to subjectivity, which relate to the use of alcohol associated with driving, lack of use of front and rear safety equipment and helmets, and the disrespect to signalization and to the National Traffic Code (Malta et al., 2011).

In the Americas and around the world, alcohol is the main risk factor for death and disability of individuals aged between 15 and 49 years. Trauma due to traffic accidents, for example, account for 9.4 and 9.0 of deaths or disabilities, respectively, and are associated with acute consumption in the 
Americas. These data corroborate with the characteristics of individuals victims of the fatal combination between alcohol and driving vehicles, which international research describe to be more frequent during the period from 6 p.m. to 6 a.m. on weekends and among young individuals (19 to 39 years) of the male sex (OPS, 2015; Campos et al., 2012).

In Brazil, the research differ in the level of association between driving under the influence of alcohol and deaths as a result of the method and circumstances in which the data were collected. For example, two studies analyzed, by the medical records of fatal victims of traffic accidents, the blood alcohol level of those who checked in at the Institute of Forensic Medicine of the cities of Porto Alegre and Rio de Janeiro, from 2001 to 2004. Both studies found that $54.2 \%$ of the fatalities from traffic accidents in Porto Alegre and 42.5\% of the fatalities in Rio de Janeiro showed blood alcohol levels exceeding $6 \mathrm{mg} / \mathrm{dl}$. Recently, the Ministry of Health disclosed the results of the Program of Monitoring of Violence and Accidents, which found that $22.3 \%$ of traffic accident victims cared for in 71 urgent and emergency services of the Brazilian National Health System (SUS) showed signs of drunkenness or confirmed alcohol consumption (Abreu; Lima; Griep, 2009; Brasil, 2012; Gomes et al., 2010).

The ideas of fate, divine will, or intention that the term "accident" gives to the causes that originated it must be considered. Given that traffic conflicts that had as outcome injuries and deaths being equaled to the practice of violence - in case the violence in traffic (Silva, 2013).

In the common sense of many people and many official documents, sometimes the State, sometimes individuals are singled out as being responsible. The responsibility of the State is the absence of public policies or inefficiency of the legislation to prevent and punish driving under the influence of alcohol. Individual responsibility falls upon those individuals who present risk behaviors (Castiel; Álvarez-Dardet, 2007).

However, it is unclear which level of governance, for example, the traffic legislation, health programs, or even individuals have on the structural economic factors that act to determine the problem is unclear.
Given the aforementioned, this theoretical essay aims to reflect, in the light of the concepts of biopower and symbolic market, on the modalities of social intervention in the confrontation of lesions and deaths caused by traffic accidents related to the consumption of alcoholic beverages, namely: the traffic legislation regarding the process of democratization; the National Policy for Reducing Morbidity and Mortality by Accidents and Violence in its philosophical axis, oriented towards the health promotion; and the advertising of alcohol and risk communication concerning the production of subjectivity of the individuals.

\section{The Traffic Legislation and the National Policy for Reducing Violence in Traffic: between the State responsibility and the individual accountability}

\section{The State}

Abramovici (2015) describes a brief history of social representations attributed to the fatal combination between alcohol and driving in France that illustrates the resistance in understanding the phenomenon as a problem. In 1900, for example, the consequences of amnesia caused by consumption of wine were treated as simple confusion. In 1959, the first laboratory devices based on blood samples were promulgated to repress those who drove under the influence of alcohol. In the 1970s, driving while drunk was still an extenuating circumstance, in spite of the 18 thousand deaths in French roads accounted for in 1972.

In Brazil, if we compare the National Traffic Codes of 1966 and 1997 (BRASIL, 1966, 1997), we can see that in the first, regulated by law No. 5,108, of September 21, 1966, the term alcohol (understood as the problems related to alcohol consumption) is mentioned only twice. In this Code, the penalties attributed for driving in a state of alcoholic intoxication or under the effect of toxic substance of any nature, were: a) warning; b) fine; c) seizure of the driving license document; d) forfeiture of the license; 
e) removal of the vehicle); f) retention of the vehicle; and g) vehicle apprehension. We can see, following what happened in France, the mild form of the penalties attributed to the problem. In the second Brazilian National Traffic Code (CTB), enacted by law No. 9,503, of September 23, 1997, the term is mentioned 27 times, however, both mentioned that the application of the penalties foreseen in the Codes did not relieve the offender of the civil sanctions and appropriate penalties provided for in the Brazilian Penal Code.

Indeed, the CTB assimilated the new social representations established by the public agendas of the world health sector when, from the 1980s, the World Health Organization (WHO) began to list violence, including traffic lesion and fatalities involving drunkenness, as a relevant problem for public health.

At the time, in Brazil, external causes began to occupy the position of second most common cause of death. However, the different types of violence, among them lesions and deaths caused by traffic accidents, were treated primarily as a problem of public safety by the Brazilian Government. It was only from 1993 on, the year that coincides with the process of democratization of the country, that the health sector began to officially assume them as a problem. In 2001, the country formulated a specific health public policy through the Ministerial Decree MS/GM no. 757, of May 16, 2001, called the National Policy for Reducing Morbidity and Mortality by Accidents and Violence (PNRMAV) (Minayo; Deslandes, 2007).

Silva (2013) ensures that the new Traffic Code was designed mainly to promote civic consciousness and human dignity, always in favor of combating violence. To the CTB, traffic is constituted by several interactions (of the human being with the machine, the citizen with the traffic authority, the manufacturer of the motor vehicle with communication and publicity), which makes necessary the application of new academic knowledge to this understanding.

Minayo and Deslandes (2007) assess the PNRMAV innovated when electing health promotion as it central axis and philosophical paradigm, with its objectives oriented to the development of actions of civic consciousness and stimulation of the culture of peace through, for example, the adoption of safe and healthy environments and behaviors. Five other guidelines are proposed by the health sector policy of the country: monitoring of the occurrences; pre-hospital care of the victims; interdisciplinary and intersectoral assistance to victims; care focused on recovery and rehabilitation; and training of Human Resources.

Notably, the two initiatives found a great ally to the scope of their purposes, when the "Lei Seca" [prohibition law] was regulated (Law No. 11,705, of June 19, 2008). Despite having been implemented nearly a decade after the regulation of CTB and PNRMAV, Lei Seca allowed public institutions to oversee, fine, and prevent traffic accidents related to alcohol consumption, through the breath test in sobriety checkpoints (blood ethanol concentration of $0.2 \mathrm{~g} / \mathrm{L}$ ). In 2012, the legislation increased the fine, doubling the value in case of recurrence of driving under the influence of alcohol (Law No. 12,670, December 2012).

When assessing the process of democratization of traffic by CTB, guideline advocated by the municipalization of traffic, Silva (2013) deems it to be problematic. The author states the fact that the municipality assumes new responsibilities in the administration of the movement of its citizens and their vehicles, despite the close relationship between land use and traffic, can be at the heart of the problem. In 2013 , only $25 \%$ of the 5,575 Brazilian municipalities took over the management and administration of traffic (Oliveira, 2016; Silva, 2013).

Assessing the health promotion guideline on PNRMAV, Minayo and Deslandes (2007) found that, despite the importance given to the health sector by public administrators of five Brazilian capitals, they evaluated the notions as being fragile from the political and technical point of view, when can be observed, for example, little financial investment and the absence of trained staff.

Regarding the impact of Lei Seca, data from the II National Survey of Alcohol and Drugs (LENAD) show a positive change in the behavior of driving under the influence of alcohol after the changes in the legislation. When comparing with data obtained in 2006 and 2012, there has been a fall of $21 \%$ of individuals who reported having driven after drinking alcohol 
(Instituto Nacional de Ciência e Tecnologia para Políticas Públicas do Álcool e Outras Drogas, 2012).

Malta et al. (2010) assessed the impact of the Lei Seca on mortality in the country, finding a reduction in 17 of the 27 Brazilian cities in the number of deaths in the second half of 2008 , compared with the year of 2007 - which is an excellent result if we take into account the number of spared lives.

However, the same authors verified that the reduction was not homogeneous among the states, being more expressive in the capitals, due to the greater availability of breathalyzers in the sobriety checkpoints from these cities. This was the case of Amazonas and of its capital, Manaus, geographical units that, in the same period analyzed, showed positive variation in the number of deaths of $5.5 \%$ and $2.7 \%$, respectively (Malta et al., 2010).

If we also evaluate when the Brazilian legislation increased the rigor concerning the maximum alcohol level (blood ethanol concentration of 0.2 $\mathrm{g} / \mathrm{L}$ ), we can realize that it was belatedly applied considering that Norway was the first country to adopt the limit of 0.5 g/L in 1936 (Leyton; Ponce; Andreuccetti, 2009).

This might be one of the reasons why Minayo and Deslandes (2007, p. 17) state: "No subject has provoked and continues to provoke so many resistances regarding its inclusion in the agenda of the sectors such as violence."

\section{The individual}

To Castiel and Álvarez-Dardet (2007), the idea of accountability, in general terms, involves primarily the notion of duty or obligation of individuals to account for certain actions to instances of regulation, whether those actions are their own, from third parties, or concerning objects that, through some kind of commitment, were entrusted to them. The association with guilt is almost inevitable, which is an unstable theme we will not deepen.

It is worth registering the embargoes that the State apparatus suffer in the use of existing legal and technical devices to produce proof of guilt in cases in which the offender driver is caught driving under the influence of alcohol or drugs. These issues can be deepened in Gonçalves (2013), who examined the controversies around the mandatory use of the breathalyzer when producing evidence of intoxication; and in Morais (2012), who found that the interpretative controversies of traffic accidents due to drunkenness constitute, in fact, in intentional homicide and not just a crime of manslaughter. Both illustrate the complexity regarding guilt.

In social representations often prevails the idea that the exercise of accountability strengthens the individual character and moral capacity, and the assumption that behavioral interventions may be significantly more effective in relation to costs than traditional service provision. This gives the impression that each individual is bearer of the necessary control devices to manage exposure to certain illnesses (Castiel; Álvarez-Dardet, 2007).

Risk management as a practice in health policy is a new look at the regulatory framework that defines the contemporary citizen (homo medicus) by the imperative of perfect health, which reproduces the ambition to eradicate the risks from the condemnation of risk behavior and the adoption of preventive measures. Thus, individuals are encouraged to increasingly behave as entrepreneurs of themselves and their health, life, and environment, which is a biossociability determined by Foucault's Biopower Structure (Nunes, 2009; Rabinow; Rose, 2006; Pogrebinschi, 2004).

Biopower is a totalizing term that ensures a global form of domination over life. From the paradigmatic point of view, it is a form of neo-Marxist interpretation that recognizes power acting as a form of expropriation of some types of added value of human life (Ferreira Neto; Kind, 2011; Ferreira Neto et al., 2009; Junges, 2009; Rabinow; Rose, 2006; Foucault, 1979).

However, biopower materializes through biopolitics, i.e., through the ways that the State uses to discipline, regulate, and control the population, which, throughout history, has taken on different forms.

In the classical era, the sovereign State (sovereign society) materialized in the figure of the monarch who owned the territory (as well as everything in it) had power over the life and death of individuals, i.e., to cause death or let live by the power of war or capital punishment. From the $17^{\text {th }}$ century, in the passage of the monarchical State to the modern 
State, political power assumed the task of managing life through the discipline of bodies or regulatory control of the populations. From there, the two poles around which develops the power of life are configured: the anatomopolitical discipline of the individual bodies (disciplinary societies) and the biopolitical regulation of the populations (control societies) (Ferreira Neto; Kind, 2011; Ferreira Neto et al., 2009; Junges, 2009; Rabinow; Rose, 2006; Foucault, 1988).

Disciplinary societies are pursued in the context of disciplinary institutions in the social fabric, such as nursing homes, factories, schools, families, hospitals, universities. Although disciplinary mechanisms precede the period that Foucault called "disciplinary societies," it is from there that a new system of domination, exercised at a distance through the progressive extensionality among spaces of domination, to the extent that the individual continues to move from one discipline space to another, such as, for instance, family-factory-family (and eventually, prison or hospital), each seeking to print in the soul a form of coercion (Junges, 2009; Rabinow; Rose, 2006; Pogrebinschi, 2004; Foucault, 1988).

From the second half of the $2 \mathrm{O}^{\text {th }}$ century, there has been a proliferation of major regulations and controls, sometimes manifested in micro level (substate, laws), sometimes manifested in the macro level (new geography of the world organized into economic blocs) (Junges, 2009; Rabinow; Rose, 2006; Pogrebinschi, 2004; Foucault, 1988).

Control societies would not be regulated only by these old institutions. The passage of a form of domination to the other occurred when the economy of power noticed that discipline was more effective and profitable than punish. In both cases, the biopower-biossociabilities control is present, the first being more direct, and the second more subtle, with consumerist and symbolic characteristics (Junges, 2009; Rabinow; Rose, 2006; Pogrebinschi, 2004; Foucault, 1988).

Given these transformations, Foucault, from the half of the 1970s, started to use the concept of governmentality (or device) to seize the emergence and characteristics of a whole variety of ways to discuss and act on individual and collective behavior on behalf of certain goals that do not have the State as their source or single reference point (Rabinow; Rose, 2006; Foucault, 1979).

Rabinow and Rose (2006) also highlight that Foucault moved away from the vision of biopower over life being just nefarious. For them, this inflection of critical analysis demonstrated Foucault's fascination by ancient modes of subjectivation and the possibilities of freedom produced through biopower.

According to Prado (2013), the devices of the control society organized by the logic of economic agents have in media communication their main vector of dissemination, which also exalts the figure of the consumer-citizen oriented by neoliberal Government rationality. They are already inserted in a new logic of biopower, based on discursive technologies that modify happiness (Prado, 2013; Freire Filho, 2008).

In the discourses that modify the biopolitics of the market, there is a demarcation line established between the validated modes and styles of life (which gain visibility) and those who are relegated to a less qualified existence. The matter is to know how the subjectivization derived from this demarcation prevent or expose individuals to risk (Prado, 2013).

If we take as an example the classic film Rebel Without a Cause, in which James Byron Dean plays a young man in love with speed, we can perceive that the lifestyle that has visibility is the one exposed to risk. On the opposite side, we would have individuals with more modest behaviors.

\section{The advertisement of alcoholic beverages: between self-regulation and restrictive regulation}

Communication in the light of the theory of symbolic market operates like a market, a place where the meanings are produced, circulated and consumed. Meanings are produced with a set of texts articulated in the discursive practice of communication. People and discursive communities participating of this market negotiate their own way of perceiving, classifying, and intervening on the world and society, searching for symbolic power. Symbolic power is, therefore, the power to make one see and believe, and has communication as an 
important vector. In other words, is the power to make people look at the world and act on it through a particular perspective (Araújo, 2004).

The production of the meanings in the current phase of modernization of the globalized capitalist system (scientific-technical-informational) exacerbated the dispute among the most important development agents of social meanings (school, family, and media), since the information and communication systems acquired greater importance, this associated with the technical-scientific factor (when science began to be used in production) from the previous period, allowing the immediacy of times and places as well as the universality and uniqueness of the techniques.

Media communication, materialized in advertising, disputes with family and school the hegemony of influence in the formation of values, choices, and attitudes of the individual.

Freire Filho (2008) notes that the images of civic consciousness that the media offers young people adjust to the neoliberal paradigm of the consumercitizen, which altered the exercise of civic consciousness. The antagonistic nature of the two concepts (consumer-citizen, a concept designed by Mexican philosopher Néstor Canclini) does not advocate engagement to the civic potential of consumption, that because civic consciousness must manifest itself through the free exercise of individual choice among a variety of structured options on the market. According to the author, the biggest problem lies in the framing of these provisions within an ethics of solipsistic success that is fundamentally devoid of solidarity concerns with the development of social justice and common well-being.

In public health, econometric studies conducted at the international level show that the content of advertising messages work both in the decision-making process of the individual, as in the increase of the general consumption of alcohol. Advertisements of alcoholic beverage emphasize themes and appeals related to the anxiolytic effect of the product, but are also associated with national symbols, always highlighting positive characteristics (Vendrame; Pinsky, 2011; Faria et al., 2011; Gomes et al., 2010; Abreu; Lima; Griep, 2009; Pinsky; Pavarino Filho, 2007)
The marketing strategies of alcoholic beverages industries tend to be globally designed and applied. The media defend self-regulation, which is a kind of code of ethics that would ban messages directed at children and adolescents and abusive and irresponsible consumption of alcohol, which in practice does not work, as noted by Vendrame and Pinsky (2011), who made their study based on a systematic literature review.

The marketing strategies of the alcoholic beverage industries only take into account the increase in sales and the conquest of new consumers, i.e., the intentional effects, even if they are directed to people aged under 18 years and that encourage abusive consumption of alcohol (Vendrame; Pinsky, 2011; Falcao; Rangel-S, 2010).

The communication model adopted in the advertisements of alcoholic beverages, for example, is mass media, developed in the post-war context in the United States to be used for mass manipulation, which the philosophers Theodor Wiesengrund-Adorno and Max Horkheimer called Culture industry. This is based on the hypodermic theory, also known as the "magic bullet," according to which the media would be able to modify people's attitudes and thoughts. This communication system, also known as Mathematical Model of Communication, developed by the American mathematicians Claude Shannon and Warren Weaver in 1948, is regarded as a one-way channel, because it prioritized the transfer of the message from one pole to another, with minimum interference (noise) (Araújo; Cardoso, 2007; Rangel-S, 2007; Araujo, 2004).

In Brazil, according to Falcão and Rangel-S (2010), the regulation of alcoholic beverage advertising occupies the agenda of our parliamentarians (congressman and senators) of the National Congress since 1956. However, it was in 2003 that the subject entered the governmental agenda from the formation of an inter-ministerial working group to discuss and propose measures for the development of the National Policy on Alcohol. The group was coordinated by the Ministry of Health and comprised by representatives from 14 federal institutes, as well as the participation of society. For the 2001 PNRMAV, the objects are accidents 
and violence, considering the consumption of alcoholic beverages as one of the causes. To the National Policy on Alcohol, the object is production and consumption, with the accidents and violence being the outcomes (Falcão; Rangel-S, 2010; Brasil, 2005).

In 2005 , the proposed regulations for advertising of the sector was appreciated by society through consultation and public hearing sponsored by the National Health Surveillance Agency (Anvisa). The request, after two extensions, was available for 120 days, received 157 contributions, with 51 in favor of a total ban, 58 in favor of regulation, 17 contrary manifestations, and 31 varied contributions (Brasil, 2005).

In short, the debate on the regulation of advertising in the sector established two sets of divergent entities and propositions.

The first consisted of entities that manifested for the prohibition of advertising. These were represented by the Civic Alliance for Control of Alcohol (Acca), established in 2003, from the Movement Advertising Without Alcohol, an initiative of the Research Unit in Alcohol and Drugs of the Department of Psychiatry of the Federal University of São Paulo, which gathered several organized and non-organized entities of civil society, and which worked with chemical dependency, support, and self-help groups, defense of people with pathologies, among others (Brasil, 2005).

The second, in the opposite side, defended the principle of freedom of expression. It was represented by commercial entities such as: National Association of Magazine Publishers (Aner); Brazilian Association of Radio and Television Broadcasters (Abert); National Council of Advertising Self-regulation (Conar); Brazilian Association of Advertisers (ABA); Brazilian Association of Beverages (Abrabe); National Association of Newspapers (ANJ); and National Union of the Beer Industry (Sindicerv). The reasons for this position were the varied: legal impediment (regulating the labeling of alcoholic beverages is a duty of the Ministry of Agriculture, Livestock and Food Supply) and ethical ("defending continuously and incessantly the principle of freedom of expression," words of the Grupo Abril, publisher of over 50 magazines, including Veja and Exame) (Brasil, 2005).

Despite the confrontation of diverging interests, in 2007 the Government published Decree no, 6,177, of May 22, 2007, which approved the National Policy on Alcohol and changed the concept of alcoholic beverage from $15^{\circ}$ to $0.5^{\circ}$ Gay-Lussac. For the entities and administrators who defended increased sanitary regulation on the matter, the legal definition of alcoholic beverages was the biggest hindrance, given that the previous legislation considered as alcoholic beverages only drinks with alcohol content exceeding $13^{\circ}$ Gay-Lussac, which, for example, does not apply to beers, wines and the so-called ice products that mix alcohol with fruit juices, soft drinks and water (Falcão; Rangel-S, 2010; Brasil, 2005).

Since 2008, three Public Civil Actions are pending in the Federal Court, filed in the states of Rio Grande do Sul, Paraná, and Santa Catarina, whose purposes are to restrict, throughout the national territory, the disclosing of commercial advertisements of beers and other beverages having an alcoholic strength equal to or greater than $0.5^{\circ}$ Gay-Lussac, in the Brazilian radio and television stations, to the hours between 9 p.m. and 6 a.m.

In December 2014, court of appeals judge Luís Alberto D'Azevedo Aurvalle (of the $4^{\text {th }}$ Chamber of the Federal Regional Court of the $4^{\text {th }}$ Region), ruled in favor of the Public Civil Actions, establishing the deadline of 180 days for their implementation, namely, the restriction of advertising on the radio and television in Brazil (Brasil, 2014).

However, in April 2015, the Supreme Court rejected the action of unconstitutionality by omission of the Legislative power, filed by the Attorney General's Office, and, consequently, the suit filed by the Federal Public Ministry denouncing that beers and wines were not covered by Law 9,294/96. The decision, dispatched by Minister Carmen Lúcia, also suspends the decision of the $4^{\text {th }}$ Chamber of the Federal Regional Court of the $4^{\text {th }}$ Region to restrict advertisement to the hours between 11 p.m. and 6 a.m. (Brasil, 2015).

Thus, currently, there is no time restriction for advertising of those beverages, and neither an obligation of warning about the risks to health and life. It is necessary to press the Legislative power to promote a definitive change. 


\section{Risk communication: between the probability of the event and social mobilization for behavior change}

Rangel-S (2007) discussed the risk communication developed and included in the legislation of the United States in the 1980s and 1990s, the Clean Air Act Amendments, as a technological device to control risk, protect, and promote health.

According to the author, in Brazil, as well as in other Western countries, the communication of risk appears in the Theory of Risk Society formulated by Ulrich Beck, German professor of Sociology at the University of Munich. The theory states that the risk originates, in part, from the limits of instrumental rationality of the industry and science to ensure certainty about what we use and consume. That is, the genesis of the risk is the limitation of science itself to find out, recognize, and control risks in society, given the historical evidence of great technological disasters. This would justify the need for sanitary regulations to protect the population and promote their health and environmental interests (Rangel-S, 2007).

Thus, regulation is incorporated as a policy by Government institutes of the State in order to reestablish the credibility and confidence regarding ongoing technological processes in society. Confidencebuilding is seen tied to perception, knowledge, and concern for the public well-being (Rangel-S, 2007).

The idea of risk analysis comes from a set of knowledge that have as bigger aim to measure the probability of occurrence of an adverse effect for a physical, chemical, or biological agent with repercussions on health, and even leading to death (Rangel-S, 2007).

For Freitas and Porto (2006), risk analysis is a political action aimed at the formation of social consensus in decision-making, rather than a technical response to collective concerns. The underlying object would be to depoliticize the debates involving the acceptability of risks, by transforming social, political, and economic choices into purely technical and scientific problems, neglecting the social dimension, the aspect of subjectivity and the technological uncertainties - because it is a fact that scientists determine risks, while the populations perceive them, and this is a point of divergence in a dialogue about risks.

Another problematic aspect of the communication of risk evoked by Beck concerns the dynamics of the mechanisms of communication itself. According to the author, there are times when communication is, in itself, a risk, or enhances the risks related to the ways in which media communication participates in the construction of the risk society (Rangel-S, 2007).

Paradoxically, in this case, communication would act in stimulating the consumption of goods and services of interest to the health (protective equipment), in line with their market interests and the interest of the goods-producing industries, which would enshrine the idea of State as a structural selectivity, as named by the German sociologist Claus Offe ${ }^{2}$.

In addition, Rangel-S (2007) allerts, risk communication is more than to explain technical data more clearly or disclose numbers for lay audiences. For communication to be successful, more than comparative explanations or illustrations with graphics and written materials are necessary. Communication is seen as a complex process that requires a set of specific techniques, as well as awareness of factors affecting the communication process and, mainly, the perception of individuals who receive risk information.

For Silva (2013), that is also another problematic matter, as he argues that the preventive approach of traffic accidents, for it to be more effective, requires tools that exceed advertising campaigns and education methods which are merely expository, typical of the traditional traffic safety that prioritizes actions guided by the triple E - Engineering, Education and legal Effort.

\footnotetext{
2 The theory of the State as a structural selectivity understands that it would be the State's duty to protect the material production by legal apparatus, whose content privileges private accumulation. Determinations of social development are not object of this State, except those whose services demanded by social policies are consistent with market mechanisms with which it should keep a strong relationship (Rodrigues, 1997)
} 
Finally, Rangel-S (2007) highlights that, although the understanding that we need to hear others is growing (in order to interest them, so that communication can be effective), the question of power (political dimension of communication) and asymmetries in the process of communication are not sufficiently considered, because, added to the bioethical aspects involved in the communicative action upon risk communication, the concerns are redoubled.

In another direction, Toro and Werneck (1997) argue for the communication for social mobilization, based on the concept of mobilization of individuals for the generation of new meanings that circulate in a given society. Change is at the core of social mobilization, geared by an ethical project of society, seeking a new way of joint coexistence between the social actors and new meanings for the future. The authors claim that mobilizing is to summon wills to act in the pursuit of a common purpose, under an interpretation and meaning also shared, being, therefore, a communication action, as it provides for the sharing of meanings and freedoms inherent to the act of offering voluntarily to the convocation (unlike being persuaded).

This perspective of communication needs planning for the purpose of accurately design objectives and goals to be achieved, also requiring skills and negotiation strategies for distribution of tasks and responsibilities.

According to the authors, the biggest challenge for the implementation of communication aimed at social mobilization in public health programs and policies is due to its verticalization character, which does not provide, through the allocation of financial resources, community participation activities. As an example, they point out the program of control of diseases transmitted by vectors, which have in chemical interventions (spraying) its main component, which, from the point of view of effectiveness and sustainability, is expensive, fragile, and dangerous, since it did not encourage the population to take part in the elimination of water reservoirs in their homes, which are conducive to the reproduction of the larvae (Toro; Werneck, 1997).

\section{Tacking the symbolic notions of market and of biopower in the production of subjectivities related to traffic violence}

We have seen that the subjectivity of the market operationalized by the communication media is evoked by the idea of self-regulation, which is strongly anchored to the principle of freedom of expression, but also in other individual freedoms freedom of choice, to come and go etc.

The central value that freedom from the liberal theory assumed in modern democratic societies is noteworthy. Being "free" is a right sought by all and a pleasure to be enjoyed in the private sphere. Thus, it became a quality driven to expand the possibilities of choice, expression, and individual achievement (Mattos; Castro, 2016).

Currently, this idea is reproduced in the speech of the common sense of many people, but also in numerous political, economic, and social practices, as the main value to be sought, which must be defended by the State and assured to society. However, it obscures little explored issues whose implications can undermine public health programs initiatives targeted at popular mobilization, even before they are created. (Mattos; Castro, 2016; Mattos, 2011).

Mattos (2011) inquires about what remains outside the idea of a free individual as someone who makes choices and takes responsibility for them.

For the author, the negative consequences related to the way that the idea of freedom was suitable for consumer culture are not mentioned. Overvaluing individuality in the private sphere promotes a growing estrangement of individuals to collective problems (Mattos, 2011).

Still according to Mattos (2011), the process generates a "depoliticization," i.e., the individuals involved with personal fulfillment and guarantee of their freedoms (of coming and going, of expression, of belief) are at risk of not taking part of collective issues, problems of public space, limiting themselves to a utilitarian relationship with politics. The policy, in this case, would be used as stage of dispute, through representation, of different 
individual interests, organized into groups and parties (Mattos, 2011).

In addition, it is outside the conflictual dimension of disagreement and tension produced within the experience of freedom, a dimension usually minimized by liberal approaches. The discomfort that can occur in the exercise of freedom arise from acts that inevitably involve other individuals, disrupt boundaries, bring into question established customs and conventions. This question can be expressed in the famous words of Pablo Neruda of critique of free will: "You are free to choose, but you are not free from the consequences of your choice."

Therefore, to think of freedom makes us (re) think individual responsibility, which, in its turn, leads us to speak of the concept of individual.

Minayo (2001) assesses that, in the field of health, the subject is conceived as the random or noise, which suggests that the medical knowledge and public health has systematically deleted the individual. The positivist perspective that considers the social as object or fact in biomedical sciences tends to transform sick individuals in biological and chemical laws. This suggests that it cared more about the logic of medical illness than with the sociology of the subject (Minayo, 2001).

In the paradigm of historical-dialectic materialism, knowingly structuralist, the role of the individual is conformed from Sartre's Existentialist Marxism current. This current has proposed to rethink the relationship between individual and structure, through organic connections that explain the interrelationships between the determinations that constitute the wholes (Minayo, 2001).

The Marxist Existentialist perspective assumes that men are at the same time product of their own product and a historical agent who cannot, under any circumstances, pass as a product (Minayo, 2001).

Individuals are always active in the production of subjectivities that should not just be considered as those linked to emotion, feeling, and affectivity.

For Morin (1996; Morin, 1991 apud Ninis; Bilibio, 2012), human subjectivity is in the relationship with the objective world, and are always uncertain, subject to produce error and disorder. In his words, it carries in itself a side of madness, illusion, confusion, which represents its demens side. Morin states that the term homo sapiens, representing the rational man, must be applied with restrictions, because the homo is also demens and ludens; faber and ludens; empiricus and imaginarius; economicus and consumans; prosaicus and poeticus.

Thus, individuals in society are complex beings or, as named by Morin, they are trine beings, i.e., at the same time social, biological, and individual (Morin, 1991 apud Ninis; Bilibio, 2012).

Revisiting the idea of individualism, but in an optimistic perspective, Ferreira (2000) develops from Jürger Habermas the argument that it is possible to build human solidarity relations amid the modern cult to the "Ego." For the author, solidarity cannot be merely rhetoric, since it is, first, an instrument and object of human effort to overcome domination. A completely independent individual would not be, for him, more than a myth, a mythological creature that bites its own tail, devours itself in a state of permanent starvation (Ferreira, 200o).

Propose social mobilization as a way to evoke solidarity exactly because we must defend our interests as social beings may seem paradoxical, but it seems to us a way to be promoted in social interventions related to traffic accidents.

What we would like to emphasize is that there is not a linear explanatory determination for the thousands of lesions and deaths caused by traffic accident, but a complex interrelation between political and economic options, the organization mode of the global economy, incentives to certain individual choices in terms of taste, and the behavior of drivers, all acting simultaneously and interdependently in the process with several spatial and temporal scales involved, in which the uncertainty degree is not always amenable to probabilistic measurements.

\section{Final remarks}

The analysis of the legal and financial apparatus of induction of production and consumption of alcoholic beverages through advertising proved to be important factors that act on the social determination of traffic violence, in which the traffic legislation and health policy of reducing morbidity and mortality from traffic accidents have little governance, either because of the lack of consensus 
in the legal power regarding what is defined as alcoholic beverage ( 13 or $0.5^{\circ}$ Gay-Lussac), or because of the prestige that the alcohol industry has in the Legislative power, responsible for creating and altering the legislation.

We observed that advertising alcoholic beverages and Lei Seca, another form of social intervention in the confrontation of the problem, operate antagonistically in the individuals. Advertising, protected by legal and financial apparatus of induction of production and consumption of alcoholic beverages, produce meanings shaped almost as a apologia, extolling freedom of choice; while the Lei Seca transfers to individuals the responsibility for the risk.

The adoption of a State action consistent with the expanded concept of health would not permit the manufacture of high-performance vehicles and motorcycles neither an apologia to alcohol consumption through advertising, without thinking about the lesions and deaths of thousands of people in traffic accidents, which results from this dangerous combination. This is not consistent with the concept of a democratic nation that established health as a universal right and duty of the State, guaranteed by social and economic policies aimed at reducing the risk of diseases and other grievances.

Transfer to the individual the responsibility of risk behavior contrasts with the limits and difficulties of intervention by the State in the regulation of forms of contamination and pollution to which all citizens are exposed.

In a more ethical perspective, risk communication must consider the limits of instrumental rationality to ensure the certainty of risk analysis, i.e., beginning from the premise that there is, in fact, a limitation of science to find out, recognize, and control risks in society.

That perspective is being designed through the blossoming of new social struggles, at the global level, the prohibition of advertising of alcoholic beverages and reduction of the damage attributable to consumption. They reveal social networking arrangements of production of public policies structured by links of many natures around an alternative health agenda (Vendrame; Pinsky, 2011; Junqueira, 200o).
In addition to the Civic Alliance for Control of Alcohol, as mentioned previously, there are two international social movements concerned with the prohibition of advertising of alcoholic beverages and resulting damage reduction: the Global Alcohol Policy Alliance (Gapa) - activism emerged in 2000, in New York, which gathers various other movements in Europe, Asia and Oceania; and the European Alcohol Policy Alliance (Eurocare), which gathers 24 countries of Europe. According to Agante (2010), both act in a perspective of reducing alcoholrelated harm in the world, by promoting policies based on existing scientific knowledge, regardless of commercial interests.

In a way, these new social struggles, at the global level, are preaching that the coping strategies of the problems related to the consumption of alcoholic beverages should be planned globally, since the marketing of alcoholic beverages industries operate in a globally articulated form.

\section{References}

ABRAMOVICI, F. Médecine et conduite automobile: alcool... et autres toxiques. La Presse Médicale, Amsterdam, v. 44, n. 10, p. 1048-1054, 2015.

ABREU, A. M. M.; LIMA, J. M. B.; GRIEP, R. H. Acidentes de trânsito e a frequência dos exames de alcoolemia com vítimas fatais na cidade do Rio de Janeiro. Escola Anna Nery, Rio de Janeiro, v. 13, n. 1, p. 44-50, 2009.

AGANTE, D. M. C. Comportamentos relacionados com o consumo de bebidas alcoólicas durante as festas académicas nos estudantes do ensino superior. 2010. Dissertação (Mestrado em Saúde Pública) - Faculdade de Medicina da Universidade de Coimbra, Coimbra, 2010.

ARAÚJO, I. S. Mercado simbólico: um modelo de comunicação para políticas públicas. Interface - Comunicação, Saúde, Educação, Botucatu, v. 8, n. 14, p. 165-178, 2004.

ARAÚJO, I. S.; CARDOSO, J. M. Comunicação e saúde. Rio de Janeiro: Fiocruz, 2007. 
BRASIL. Lei nº 5.108, de 21 de setembro de 1966. Institui o Código Nacional de Trânsito. Diário Oficial da União, Brasília, DF, 22 set. 1966. Seção 1, p. 10917.

BRASIL. Lei nº 9.503, de 23 de setembro de 1997. Institui o Código de Trânsito Brasileiro. Diário Oficial da União, Brasília, DF, 24 set. 1997. Seção 1, p. 21201.

BRASIL. Agência Nacional de Vigilância Sanitária. Ministério da Saúde. Consulta Pública no 83/2005 - Bebidas Alcoólicas. 2005. Disponível em: <https://goo.gl/RgWbZf >. Acesso em: 27 mar. 2014.

BRASIL. Ministério da Saúde. Sistema VIVA: vigilância de violências e acidentes, 2011. Brasília, DF: Ministério da Saúde, 2012. Disponível em: <https://goo.gl/339QDV〉. Acesso em: 5 dez. 2015.

BRASIL. Ministério da Previdência Social. Conselho Nacional de Previdência Social. CNPS: Acidentes de trânsito representam uma despesa de 12 bi para a Previdência. Brasília, DF, 19 dez. 2013. Disponível em: 〈https://goo.gl/x1Srgs〉. Acesso em: 17 nov. 2015.

BRASIL. Tribunal Regional Federal ( $4{ }^{\mathrm{a}}$ Região). TRF4 restringe publicidade de cerveja e vinho em rádio e TV. Porto Alegre, 11 dez. 2014. Disponível em: <https://goo.gl/oeplcS〉. Acesso em: 20 abr. 2015.

BRASIL. Supremo Tribunal Federal. Publicidade de bebidas alcoólicas e omissão legislativa. Informativo STF Mensal, Brasília, DF, n. 48, p. 14-15, abr. 2015. Disponível em: <https://goo.gl/ xRMlRy>. Acesso em: 20 nov. 2015.

CAMPOS, V. R. et al. Beber e dirigir: características de condutores com bafômetro positivo. Revista de Psiquiatria Clínica, São Paulo, v. 39, n. 5, p. 166-171, 2012.

CASTIEL, L. D.; ÁLVAREZ-DARDET, C. A saúde persecutória: os limites da responsabilidade. Rio de Janeiro: Fiocruz, 2007.

CNM - CONFEDERAÇÃO NACIONAL DE MUNICÍPIOS. Mapeamento das mortes por acidentes de trânsito no Brasil. Estudos Técnicos CNM, Brasília, DF, v. 2, p. 201-219, 2010. Disponível em: <https://goo.gl/ej4MZ1>. Acesso em: 17 fev. 2017
FALCÃO, I. C. L.; RANGEL-S, M. L. Controle sanitário da propaganda de bebidas alcoólicas no Brasil: estudo dos projetos de lei de 1988 a 2004. Ciência \& Saúde Coletiva, Rio de Janeiro, v. 15, p. 3433-3442, 2010.

FARIA, R. et al. A propaganda de álcool e associação ao consumo de cervejas por adolescentes. Revista de Saúde Pública, São Paulo, v. 45, n. 3, p. 441-447, 2011.

FERREIRA, R. M. Individuação e socialização em Jürgen Habermas: um estudo sobre a formação discursiva da vontade. São Paulo: Annablume; Belo Horizonte: Unicentro Newton Paiva, 2000.

FERREIRA NETO, J. L.; KIND, L. Promoção da saúde: práticas grupais na estratégia saúde da família. Belo Horizonte: Fapemig, 2011.

FERREIRA NETO, J. L. et al. Apontamentos sobre promoção da saúde e biopoder. Saúde e Sociedade, São Paulo, v. 18, n. 3, p. 456-466, 2009.

FOUCAULT, M. Microfísica do poder. Rio de Janeiro: Graal, 1979.

FOUCAULT, M. História da sexualidade I: a vontade de saber. Rio de Janeiro: Graal, 1988.

FREIRE FILHO, J. Mídia, subjetividade e poder: construindo os cidadãos-consumidores do novo milênio. Lugar Comum - Estudos de Mídia, Cultura e Democracia, Rio de Janeiro, v. 1, n. 25-26, p. 89-103, maio/dez. 2008.

FREITAS, C. M.; PORTO, M. F. Saúde, ambiente e sustentabilidade. Rio de Janeiro: Fiocruz, 2006.

GOMES, L. C. D. et al. Prevalência de alcoolemia em óbitos por acidente de transporte e por outras causas externas. Revista AMRIGS, Porto Alegre, v. 54, n. 3, p. 273-277, 2010.

GONÇALVES, A. B. O bafômetro e a embriaguez no volante: análise constitucional e aspectos penais. Revista Seção Judiciária do Rio de Janeiro, Rio de Janeiro, v. 20, n. 36, p. 13-38, 2013. Disponível em: <https://goo.gl/retx4U>. Acesso em: 2 fev. 2017.

INPAD - INSTITUTO NACIONAL DE CIÊNCIA E TECNOLOGIA PARA POLÍTICAS PÚBLICAS DO ÁLCOOL E OUTRAS DROGAS. II Lenad - 
levantamento nacional de álcool e drogas. São Paulo: Universidade Federal de São Paulo, 2012.

JUNGES, J. R. Direito à saúde, biopoder e bioética. Interface - Comunicação, Saúde, Educação, Botucatu, v. 13, n. 29, p. 285-295, 2009.

JUNQUEIRA, L. A. P. Intersetorialidade, transetorialidade e redes sociais na saúde.

Revista de Administração Pública, Rio de Janeiro, v. 34, n. 6, p. 35-45, 2000.

LEYTON, V.; PONCE, J. C.; ANDREUCCETTI, G. Problemas específicos: álcool e trânsito. In: ANDRADE, A. G. et al. (Ed.) Álcool e suas consequências: uma abordagem multiconceitual. Barueri: Minha Editora, 2009. p. 163-177. Disponível em: <https://goo.gl/nBVM6T>. Acesso em: 12 out. 2014 .

MALTA, D. C. et al. Impacto da legislação restritiva do álcool na morbimortalidade por acidentes de transporte terrestre - Brasil, 2008. Epidemiologia e Serviço de Saúde, Brasília, DF, v. 19, n. 1, p. 77-78, 2010.

MALTA, D. C. et al. Análise das ocorrências das lesões no trânsito e fatores relacionados segundo resultados da Pesquisa Nacional por Amostra de Domicílios (Pnad) - Brasil, 20o8. Ciência \& Saúde Coletiva, Rio de Janeiro, v. 16, n. 9, p. 3679-3687, 2011.

MATTOS, A. R. Liberdade individual e a despolitização das escolhas: uma reflexão. Redescrições, Rio de Janeiro, v. 3, n. 1, p. 99-105, 2011. Disponível em: <http://philpapers.org/rec/ MATLIE >. Acesso em: 21 abr. 2016.

MATTOS, A. R.; CASTRO, L. R. Jovens e a liberdade: reflexões sobre autonomia, responsabilidade e independência. Psicologia \& Sociedade, Belo Horizonte, v. 28, n. 1, p. 65-73, 2016. Disponível em: <https://goo.gl/Oz2fse>. Acesso em: 21 abr. 2016.

MINAYO, M. C. S. Estrutura e sujeito, determinismo e protagonismo histórico: uma reflexão sobre a práxis da saúde coletiva. Ciência \& Saúde Coletiva, Rio de Janeiro, v. 6, n. 1, p. 7-19, 2001.

MINAYO, M. C. S.; DESLANDES, S. F. Análise diagnóstica da política nacional de saúde para redução de acidentes e violências. Rio de Janeiro: Fiocruz, 2007.

MORAIS, E. Acidentes de trânsito causados por embriaguez: dolo ou culpa do condutor. 2012. Monografia (Graduação em Direito) - Escola de Direito do Centro Universitário da Cidade do Rio de Janeiro, Rio de Janeiro, 2012.

MORIN, E. A noção do sujeito. In: SCHNITMAN, D. F. (Ed.). Novos paradigmas, cultura e subjetividade. Porto Alegre: Artes Médicas, 1996. p. 45-58.

NINIS, A. B.; BILIBIO, M. A. Homo sapiens, Homo demens e Homo degradandis: a psiquê humana e a crise ambiental. Psicologia \& Sociedade, Belo Horizonte, v. 24, n. 1, p. 46-55, 2012. Disponível em: <https://goo.gl/eQdcbH>. Acesso em: 11 nov. 2014.

NUNES, J. A. Saúde, direito à saúde e justiça sanitária. Revista Crítica de Ciências Sociais, Coimbra, n. 87, p. 143-169, 2009.

OLIVEIRA, A. M. de F. ONU - década de ações para a segurança no trânsito 2011-2020. Brasília, DF: Câmara dos Deputados, 2016. Disponível em: <https://goo.gl/u3SC8P>. Acesso em: 15 jun. 2016. OPS - ORGANIZACIÓN PANAMERICANA DE LA SALUD. Informe sobre la situación regional del consumo de alcohol y la salud en las Américas. Washington, DC, 2015. Disponível em: <www.paho. org/alcoholreport2015>. Acesso em: 11 jun. 2016.

PINSKY, I.; PAVARINO FILHO, R. V. A apologia do consumo de bebidas alcoólicas e da velocidade no trânsito no Brasil: considerações sobre a propaganda de dois problemas de saúde pública. Revista de Psiquiatria do Rio Grande do Sul, Porto Alegre, v. 29, n. 1, p. 110-118, 2007.

POGREBINSCHI, T. Foucault, para além do poder disciplinar e do biopoder. Lua Nova, São Paulo, n. 63, p. 179-201, 2004.

PRADO, J. L. A. Convocações biopolíticas dos dispositivos comunicacionais. São Paulo: Educ: Fapesp, 2013.

RABINOW, P.; ROSE, N. O conceito de biopoder hoje. Revista de Ciências Sociais, Fortaleza, n. 24, p. 27-57, abr. 2006. 
RANGEL-S, M. L. Comunicação no controle de risco à saúde e segurança na sociedade contemporânea: uma abordagem interdisciplinar. Ciência \& Saúde Coletiva, Rio de Janeiro, v. 12, n. 5, p. 1375-1385, 2007

RODRIGUES, C. M. Conceito de seletividade de políticas públicas e sua aplicação no contexto da política de extensão rural no Brasil. Cadernos de Ciência \& Tecnologia, Brasília, DF, v.14, n. 1, p.113-154, 1997.

SILVA, P. H. N. V. Violência e morte no trânsito: associações ignoradas na prevenção dos acidentes com motocicletas. Recife: UFPE, 2013.
TORO, J. B; WERNECK, N. M. D. F. Mobilização social: um modo de construir a democracia e a participação. Brasília, DF: Ministério da Justiça, 1997. Disponível em: <https://goo.gl/2ncTpT>.

Acesso em: 24 out. 2014.

VENDRAME, A.; PINSKY, I. Ineficácia da autorregulamentação das propagandas de bebidas alcoólicas: uma revisão sistemática da literatura internacional. Revista Brasileira de Psiquiatria, São Paulo, v. 33, n. 2, p. 196-202, 2011.

\section{Acknowledgments}

To Karina da Silva Silva, physical therapist and specialist in Environmental Health of the Instituto Leônidas e and Maria Deane, to Jan Bitoun, PhD. in Geography at the Universidade Federal de Pernambuco, and to Cátila Gueno de Souza, lawyer and Managing Assistant the Federal Regional Court, $4^{\text {th }}$ region for the exchanges of ideas, critical comments, and specific information.

Received: $12 / 14 / 2015$

Resubmitted: 07/22/2016

Approved: 12/05/2016 